\title{
Book Review: Dynamics of a Social Language Learning Community by Jo Mynard, Michael Burke, Daniel Hooper, Bethan Kushida, Phoebe Lyon, Ross Sampson, and Phillip Taw
}

\author{
Yuan Sang, Florida State University \\ https://orcid.org/0000-0003-2889-1223 \\ ysang@fsu.edu
}

In the field of foreign and second language (L2) education, the primary focus has been on the language teaching, learning, and language development in the L2 classroom. However, beginning from the last decade, there is a growing recognition that language teaching and learning also take place in non-classroom settings (Reinders \& Benson, 2017). Following this realization, the role of a social learning space has been increasingly emphasized in influencing and facilitating the language development of L2 learners. Social learning space as a construct refers to a place where learners can gather together and learn with and from each other through relaxed "social interaction" (Murray, 2017, p. 117). Social learning spaces have recently begun to be viewed as an indispensable context for L2 learning, although research on these social learning spaces is still in its infancy. This book (Mynard et al., 2020) is one of the first few scholarly collections that addresses this emerging area of study, and it offers intriguing insights to enrich the field's understanding of L2 learners' growth beyond the classroom. There are in total four main sections in this book, including setting the scene, case studies, exploring concepts through the research, and implications for the field.

The first four chapters in the first section set out to portray the background of the research. The first chapter provides some background information of the university and the English Lounge in the Self-Access Learning Center (SALC) where the authors work and where the study is carried out. It also introduces the research questions explored in the study, the authors' demographic information and their roles in the study, and the overall structure of the book. In the second chapter, Bethan Kushida reviews a set of past studies to examine the significant role of social learning space in language learning and its connections to several theoretical constructs. 
For instance, Menezes (2011) and Palfreyman (2014) argue that effective learners are able to determine whether to engage in particular learning opportunities and actively select the resources afforded by different learning contexts. Reinders and Benson (2017) describe these practices as "social ecologies of language learning," which take place in "an interconnected web of learning opportunities," not only in the L2 classroom but also in non-classroom settings ( $p$. 14). Based on a complex dynamic systems perspective, the author of this chapter explores the connections between social learning space and key constructs in language learning, such as learner autonomy, engagement, and identity.

Following this, the third chapter in the first section contextualizes the study in the Japanese educational environment as the macro-context for English learning. This chapter provides interesting information about English education in Japanese schools, Japan's relationship with English, and Japanese people's different perspectives toward English education (i.e., juken-eigo versus communicative-oriented English instruction). Therefore, this chapter is especially helpful for readers who are not familiar with the educational background of English in Japan. Finally, chapter four presents information about the research methods used in the study, including research setting, participants, instruments, data collection procedures, and data analytical approaches.

Starting from the second section which is also the largest part of the book, the authors present six cases on students' participation, engagement, decision-making, and reflection on learning English in the English Lounge in the SelfAccess Learning Center as a social learning space. In each of these cases, the authors focus on learners' previous learning experience of English before joining the SALC, their roles in participating in English learning in the social learning space, their various trajectories in the participation (e.g., entering, maintaining, and leaving), and how they are influenced by the learning experience in the English Lounge in terms of emotions, beliefs of English learning, relationships with other social members, and plans for future learning. These cases demonstrate that English learners come to the English Lounge with different beliefs, values, and expectations of what they hold are important and what goals they aim to achieve. During their engagement with learning English in the SALC, many students encounter a phase at the beginning where they strive and sometimes struggle to pursue and maintain membership as parts of the learning community. In addition, after they become members of the social learning space, most students go through a continuous process in which they keep on reflecting, evaluating, and examining personal identities. In these identity explorations, students usually rely on their relationships with other social members. These explorations then further impact students' participation and learning in the English Lounge.

In the third section, the authors focus on connecting their findings with theoretical constructs to explore the significance of the research results. Chapter 11 examines the role of learner identity in influencing Japanese English learners' participation in and use of the English Lounge as a social learning space. Referring to established conceptualizations of the identity construct (e.g., Benson et al., 2013), the author of this chapter conceives of six facets of identity, which are embodied identity, reflexive identity, projected identity, recognized identity, imagined identity, and identity categories and resources. Following this, these six identity facets are linked to the participants' learning performance and reflection to show how the English learners' identity construction and identity shifts over time influence their use of the English Lounge. In chapter 12, the authors investigate the connection between social learning space and communities of practice (CoP). Based on Wenger-Trayner and Wenger-Trayner (2015), CoP is conceptualized as "groups of people who share a concern or a passion for something they do and learn how to do it better as they interact regularly" (p. 1). Comparing the construct of $\mathrm{CoP}$ and the research findings of the social learning space in the Japanese university, the authors argue that a significant parallel between $\mathrm{CoP}$ and the social learning space is that they both allow students to participate at various levels. In other words, English learners who are involved in the English Lounge can be categorized into several groups depending on their levels of participation, including a core group, an active group, a peripheral group, and as outsiders. This finding echoes the conceptualization of CoP, which is thought to include domain, community, and practice as the three essential elements (e.g., Wenger et al., 2002). After this, the thirteenth chapter focuses on the relationship between learner beliefs and individual differences to explore why learners choose to use or not use the English Lounge for language learning. The authors define learner beliefs as "the ways in which individuals 
view the learning process which can have an impact on how they approach language learning" (Mynard et al., 2020, p. 186). Some additional individual difference factors examined in this chapter are the L2 motivational self system, past English learning experience, L2 anxiety, and agency. What stands out in this chapter is that each of these individual domains influences students' decision-making of whether they choose to participate in the social learning space and the ways in which they make use of the English Lounge for English learning. The authors also acknowledge that the English Lounge encompasses far more individual factors than those explored in this chapter, so more research is needed to investigate the complex dynamics of the English Lounge as a social learning space. Finally, chapter 14 reflects on the research methods applied in the research and discusses some strengths of the approaches for data collection and data analysis. For instance, the authors of this chapter find that in-field observations and semi-structured interviews are extremely helpful for collecting data for the research purposes. They also see the analytical approaches (e.g., narrative analysis, typological analysis, and interpretative analysis) as helpful for revealing in-depth information of students' learning and decision-making in the social learning space.

The last two chapters in the final section summarize the findings of the entire research project and draw readers' attention to the potential implications for practice. In chapter 15, the authors provide a recap of the significant findings in the previous chapters. From there, they present further thoughts about the future research agenda on social learning space. Next in chapter 16, the authors suggest a set of strategies for practical intervention, which are aimed to support students' learning in social learning space and structure the social learning space as a more accessible place for those students who have not taken advantage of this learning opportunity.

In all, this book is strongly driven by relevant theories and its discussions are based on empirical evidence. The authors present a number of thought-provoking findings from an ambitious research project, and these findings provide significant implications to the field of L2 education. Moreover, this book also arrives at a perfect time, since many educational practices have been moved online during the COVID-19 pandemic, and the conventional boundaries between in-class and out-of-class learning have become increasingly vague. Therefore, this book is an invaluable contribution, and it is my position that more research on language learners' L2 learning efforts and experience in non-classroom settings will help expand the field's knowledge of the complex dynamics of L2 teaching and learning.

\section{Notes on the author}

Yuan Sang received his $\mathrm{PhD}$ in foreign and second language education from the School of Teacher Education at Florida State University. His research interest lies in the area of language teacher education. Specifically, he uses a language socialization perspective to explore English teachers' language learning and identity construction in L2 teacher education in China. His research has appeared in academic journals such as Linguistics and Education and RELC Journal.

\section{REFERENCES}

Benson, P., Barkhuizen, G., Bodycott, P., \& Brown, J. (2013). Second language narratives in study abroad. Palgrave Macmillan.

Menezes, V. (2011). Affordances for language learning beyond the classroom. In P. Benson \& H. Reinders (Eds.), Beyond the language classroom (pp. 5971). Palgrave Macmillan.

Murray, G. (2017). Autonomy in the time of complexity: Lessons from beyond the classroom. Studies in
Self-Access Learning Journal, 8(2), 116-134. https://doi.org/10.37237/080205

Mynard, J., Burke, M., Hooper, D., Kushida, B., Lyon, P., Sampson, R., \& Taw, P. (2020). Dynamics of a social language learning community. Multilingual Matters.

Palfreyman, D. M. (2014). The ecology of learner autonomy. In G. Murray (Ed.), Social dimensions of autonomy in language learning (pp. 175-191). Palgrave Macmillan. 
Reinders, H., \& Benson, P. (2017). Research agenda: Language learning beyond the classroom. Language Teaching, 50(4), 561-578. https://doi.org/10.1017/S0261444817000192

Wenger, E., McDermott, R., \& Snyder, W. M. (2002). Cultivating communities of practice: A guide to managing knowledge. Harvard Business School Press.

Wenger-Trayner, E., \& Wenger-Trayner, B. (2015). Communities of practice: A brief introduction. Retrieved from http://wenger-trayner.com/wpcontent/uploads/2015/04/07-Brief-introduction-tocommunities-of-practice.pdf

\section{FULL PUBLICATION DETAILS}

Title: Dynamics of Social Language Learning Community

Authors: Jo Mynard, Michael Burke, Daniel Hooper, Bethan Kushida, Phoebe Lyon, Ross Sampson, and Phillip Taw

Date: 2020

Publisher: Multilingual Matters, Bristol, UK

Number of pages: 290

Number of chapters: 16

ISBN-13: 978-1-78892-890-8 (hbk)

ISBN-13: 978-1-78892-889-2 (pbk) 